\title{
ABUNDANCE AND SPATIAL-TEMPORAL DISTRIBUTION OF THE FAMILY PORTUNIDAE (CRUSTACEA, DECAPODA) IN THE CURUÇÁ ESTUARY ON THE NORTHERN COAST OF BRAZIL
}

\author{
Nevis, A. B.*; Martinelli, J. M.; Carvalho, A. S. S. \& Nahum, V. J. I. \\ Laboratório de Biologia Pesqueira e Manejo dos Recursos Aquáticos, Instituto de Ciências \\ Biológicas, Universidade Federal do Pará, Av. Perimetral 2651, \\ Terra Firme, Belém, PA - Brasil, CEP 66077-530 \\ *Corresponding author: abnevis@ufpa.br
}

\begin{abstract}
Nevis, A. B.; Martinelli, J. M.; Carvalho, A. S. S. \& Nahum, V. J. I. 2009. Abundance and spatial-temporal distribution of the family Portunidae (Crustacea, Decapoda) in the Curuçá estuary on the northern coast of Brazil. Braz. J. Aquat. Sci. Technol. 13(1):71-79. ISSN 1808-7035. Species composition, abundance and distribution patterns of the family Portunidae in the Curuçá estuary in the northeastern portion of the state of Pará (northern Brazil) were studied bimonthly from July 2003 to July 2004. Samples were taken with a wing trawl net during the day at ebb tide during last quarter moon. A total of 427 individuals were collected, comprising three species: Callinectes bocourti, Callinectes danae and Callinectes ornatus. C. danae was the dominant species (56\%). C. bocourti demonstrated a preference for the rainy season and $C$. ornatus preferred the dry season. $C$. danae was present in both seasons. The results indicate that variation in salinity and $\mathrm{pH}$ related to season (dry and rainy) are considered determinant factors for the distribution of $C$. bocourti and $C$. ornatus.
\end{abstract}

Keywords: Composition, Brachyura, Callinectes, swimming crab, Amazon.

\section{INTRODUCTION}

Among the more than 300 species of Decapoda from the family Portunidae that occur in the western Atlantic (Williams, 1974), 20 are found on the Brazilian coast and 11 are found on the coast of the state of Pará (northern Brazil) (Melo, 1996; Barros et al., 1997; Barros \& Pimentel 2001): Callinectes bocourti A. Milne Edwards, 1879; Callinectes danae Smith, 1869; Callinectes ornatus Ordway, 1863; Callinectes larvatus Ordway, 1863; Callinectes exasperatus (Gerstaecker, 1856); Cronius ruber Lamarck, 1818; Cronius tumidulus Stimpson, 1818; Portunus anceps Saussure, 1858; Portunus ordwayi Stimpson, 1860; Portunus rufiremus Holthuis, 1959; and Portunus spinicarpus Stimpson, 1871. These species have a preference for estuarine environments, beaches and shallow waters (Melo, 1996).

Portunidae species have rather diversified feeding habits, including algae, vascular plants, foraminiferous species, cnidarians, mollusks, polychaetes, other crustaceans, fish and other groups (Mantelatto \& Chistofoletti, 2001; Branco et al., 2002). They have ecological importance in the estuarine-marine ecosystem due to their activity as predators and are voracious hunters. They also serve as a food resource for other aquatic organisms, such as fish and coastal birds (Mantelatto, 1995). At the Curuçá estuary on the coast of the state of Pará (northern Brazil), swimming crabs are an important dietary item for the fish species Centropomus pectinatus Poey, 1860 (Cunha, 2005), Lutjanus jocu (Bloch \& Schneider, 1801) (Monteiro, 2005) and other fish of economic importance.

In North America, Europe and Japan, many swimming crab species have undergone intense economic exploitation (Baptista et al., 2003; Branco \& Fracasso, 2004). In Brazil, only the state of Santa Catarina (southern region) has a fishery targeting swimming crabs, whereas they are generally a bycatch in fish and shrimp fisheries in the most of the other regions of the country (Vieira et al., 1996; Andrade, 1998; Keunecke et al., 2008). On the coast of the state of Pará, swimming crabs serve as a food resource for the local human population, thereby constituting an important source of protein as well as a source of income in the for local commerce.

Studies on the life cycle of Portunidae have been carried out all over the world. In Brazil as well, there is a large number of studies on the biology of these organisms, but there are as yet few studies for the coast of the state of Pará. Thus, the aim of the present study was to characterize species composition, abundance 


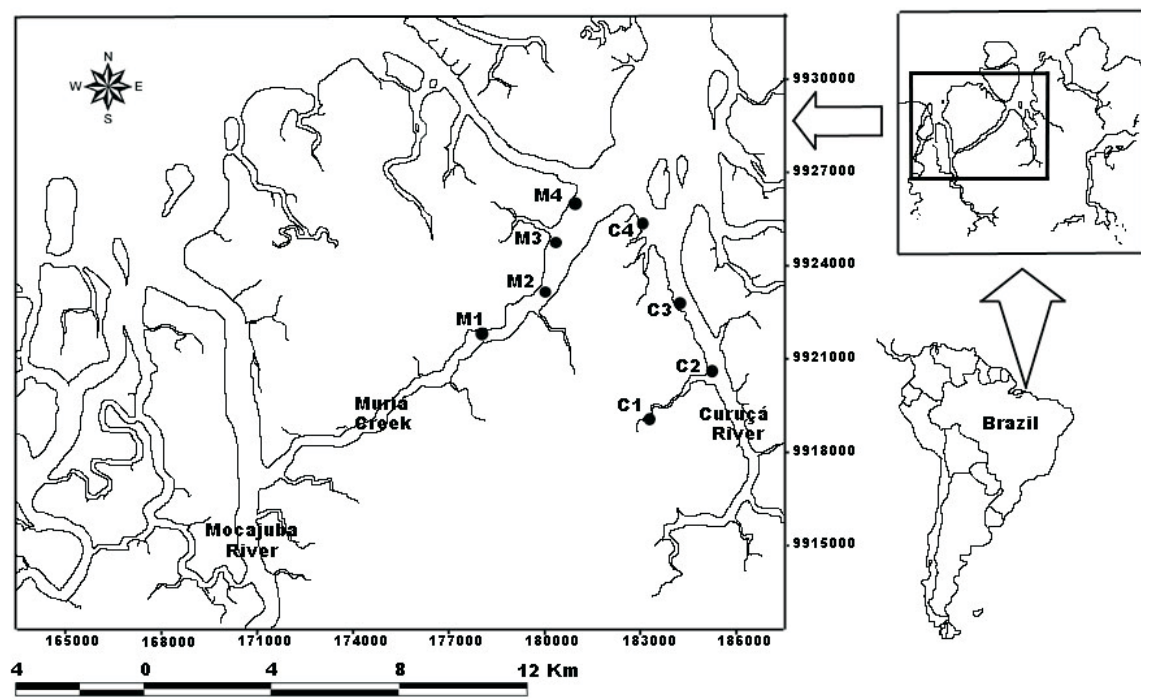

Figure 1 - Study area in the estuary or the Curuçá River, indicating the eight collection sites.

and spatial-temporal distribution of the family Portunidae in the Curuçá estuary, Pará, Brazil.

\section{MATERIALS AND METHODS}

Collections were carried out in the Curuçá estuary (Figure 1), located in the town of Curuçá in the northeastern region of the state of Pará, approximately $150 \mathrm{~km}$ from the state capital, Belém. This town makes up part of the Salgado micro-region and is bordered by the Atlantic Ocean to the north, the town of Terra Alta to the south, the town of Marapanim to the east and the town of São Caetano de Odivelas to the west. The center of town is located at the following geographic coordinates: 0043'48" S and 4751'06" W. The region has an equatorial climate, characterized by high temperatures (average of $27^{\circ} \mathrm{C}$ ) and mean annual precipitation of $2526 \mathrm{~mm}$ (Pereira et al., 2007).

The Curuçá estuary has two main intertidal mangrove creeks. One is denominated the Muriá Creek, which connects the Curuçá and Mocajuba rivers; the Abade Port is located on its margins. The other creek is the Curuçá River, with the town of Curuçá located on its banks. Four collection sites were selected along each of the creeks, denominated Creek C (C1, C2, C3 and C4; Curuçá River) and Creek M (M1, M2, M3 and M4; Muriá Creek); the sites were spaced approximately $2 \mathrm{~km}$ from one another (Figure 1). During the collections, differences in the substrate granulometry among sites were analysed using a modified method from Suguio (1973), described in Baisch et al. (2006) and by a visual method based on the accomopanying fauna of each bottom trawl. At sites C2, M2, M3 and M4, the bottom was always muddy, unlike the other sites, where the net sack always returned with a large amount of fine sand, silt and clay (C1), sponge (C3 and M1) and organic matter of a vegetal origin (C4).

Sampling was performed bimonthly from July 2003 to July 2004 , totaling seven collections. Two trawls were carried out at the collection sites during each sampling, totaling 16 samples per month and 112 in all. Trawls were performed during the day at ebb tide during the last quarter, using a wing trawl net. The net was pulled by a wooden commercial fishing boat, 9 meters in length. Each operation lasted 5 minutes, counting from the full release of the net. On each collection, the geographic position was recorded at each minute of trawling using a Global Positioning System (GPS) for the later calculation of the distance swept by the net. At the end of each sampling, swimming crabs were collected, conserved in ice and later frozen.

Temperature, salinity, $\mathrm{pH}$, dissolved oxygen (DO), suspended particulate matter (SPM) and biochemical oxygen demand (BOD) were recorded at each collection site. Temperature and salinity were measured using a conductivimeter and $\mathrm{pH}$ was measured using a potentiometer; these values were determined in the field. For the calculation of SPM, DO and BOD, 300 milliliters of water were collected for analysis.

Dissolved oxygen was done according Winkler, modified with the addition of sodium azide and the gathering of SPM and BOD followed procedures published by the Institute of the Millennium Project, available online on page http://www.mileniodomar.org.br. SPM, DO and BOD analyses were performed in the Hydrochemical Laboratory of the Geosciences Center of the Universidade Federal do Pará (UFPA). Data on precipitation during the collection period were obtained from the National Waters Agency (ANA, 2004). Due to the lack of information on precipitation in November 2003, May 2004 and July 2004, the mean monthly values 


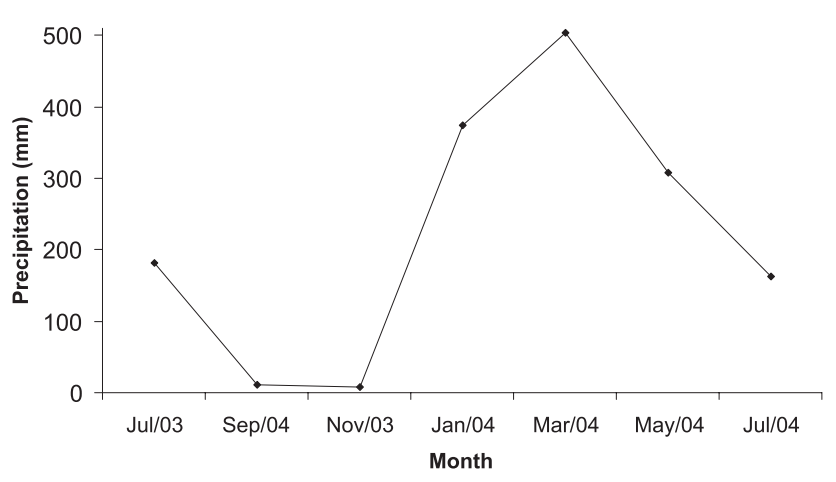

Figure 2 - Monthly precipitation for the town of Curuçá during the collection period (Source: ANA, 2005).

between 1981 and 2002 were used for the month of November 2003, whereas mean monthly values between 1981 and 2003 were used for the months of May and July 2004. The swimming crabs caught were transported to the Fishery Biology and Aquatic Resource Management Laboratory (UFPA) and kept in a freezer. After thawing, the specimens were identified to the species level using identification keys (Takeda \& Okutani, 1983; Cervigón et al., 1992; Melo, 1996).

To express the abundance of the organisms, the relative density (individuals $/ 1000 \mathrm{~m}^{2}$ ) was calculated for each site (C1 to C4; M1 to M4), creek (Curuçá and Muriá) and collection month. Density was also calculated for the climatic seasons of the year (rainy and dry). Collections in July, September and November were grouped and considered samples from the dry season, whereas collections from January, March and May were considered samples from the rainy season.

Relative density was calculated by dividing the number of individuals by the area swept on each trawl. The area swept was obtained from the following formula: $A=N M \times A C \times D T$, in which: $N M=$ net mouth $=$ $10.43 \mathrm{~m} ; A C=$ net aperture coefficient $=0.5$ (Pauly, 1980); DT = distance traveled in five minutes of trawling (m). The distance traveled was calculated from the positions obtained from the GPS during the trawls, making use of georeferenced satellite imaging on the ArcGis $8.2^{\circledR}$ computer program (ArcView and Spatial Analyst from ESRI).

The Kruskal-Wallis test was used to determine the difference in average abundance between months, creeks, collection sites and climatic seasons for the different species, as the data did not present normal distribution, even after undergoing transformations.

Average monthly density values per species were transformed by the fourth root and the Bray-Curtis similarity coefficient was used to create a similarity matrix. Cluster analysis was applied to the matrix, with the groups linked by the simple average of their similarity values (Unweighted pair-group method with arithmetic mean - UPGMA). Non-metric multidimensional scaling (MDS) was then performed.

The similarity of percentages (SIMPER) analysis allowed the indication of which species substantially contribute toward the formation of groups, defined by the cluster and MDS analyses. BIOENV analysis allowed the correlation of biotic and abiotic data, revealing which environmental parameters were more important to the distribution of species in the estuary. For this analysis, a Euclidean distance matrix was constructed with the abiotic data and Spearman's coefficient was used to correlate this matrix to the similarity matrix of the biotic data created using the Bray-Curtis coefficient.

\section{RESULTS}

The highest precipitation occurred in March 2004 and the lowest occurred in November 2003 (Figure 2). Table 1 displays the descriptive statistics of the environmental variables. There were significant differences for the averages of all abiotic factors between the months studied $(p<0.05$; Table 2$)$. The lowest temperature, salinity, $\mathrm{DO}$ and $\mathrm{pH}$ values were recorded during months with greater rainfall, whereas SPM and BOD have more expressive values in these months. Figure 3 illustrates the bimonthly variations in these environmental variables. No significant differences in environmental variables were detected between sites or creeks (Table 2).

A total of 427 individuals from the family Portunidae were found, pertaining to the following three species: Callinectes bocourti (39\%), Callinectes danae (56\%) and Callinectes ornatus (5\%). Relative abundance was $1.21 \mathrm{ind} . / 1000 \mathrm{~m}^{2}$ for $C$. bocourti, $1.77 \mathrm{ind} . / 1000 \mathrm{~m}^{2}$ for $C$. danae and 0.15 ind./1000 $\mathrm{m}^{2}$ for $C$. ornatus Abundance of the swimming crabs varied both spatially as well as temporally (Table 3; Figures 4 to 8 ). Callinectes bocourti was more abundant in the rainy season, whereas $C$. ornatus only occurred in the dry season (Figures 4 and 6). C. danae occurred throughout the year, with a peak in abundance in July 2003 and another in January 2004 (Figure 4). Thus, there as a alternation in species density throughout the year,

Table 1 - Minimum, maximum, average and standard deviation (SD) values of environmental variables recorded throughout the collection periods in the Curuçá estuary.

\begin{tabular}{lccc}
\hline \hline & Minimum & Maximum & Average $\pm \mathrm{SD}$ \\
\hline Tem perature $\left(\mathrm{C}^{\circ}\right)$ & 20.6 & 31.0 & $26.06 \pm 2.58$ \\
Salinity & 6.1 & 40.8 & $18.67 \pm 10.11$ \\
$\mathrm{pH}$ & 6.87 & 8.12 & $7.56 \pm 0.36$ \\
$\mathrm{SPM}(\mathrm{mg} / \mathrm{L})$ & 13.0 & 98.6 & $39.42 \pm 23.72$ \\
$\mathrm{DO}(\mathrm{mg} / \mathrm{L})$ & 3.45 & 8.42 & $5.67 \pm 1.15$ \\
BOD $(\mathrm{mg} / \mathrm{L})$ & 0.53 & 3.16 & $2.22 \pm 0.78$ \\
\hline
\end{tabular}


Table 2 - Results of the Kruskal-Wallis test for the abiotic factors recorded in the Curuçá estuary (PA) from July 2003 to July 2004 according to month, creek and collection site.

\begin{tabular}{|c|c|c|c|c|c|c|}
\hline \multirow{2}{*}{ FACTORS } & \multicolumn{2}{|c|}{ Month } & \multicolumn{2}{|c|}{ Creek } & \multicolumn{2}{|c|}{ Site } \\
\hline & $H$ & $p$ & $H$ & $p$ & $H$ & $p$ \\
\hline Temperature $\left(\mathrm{C}^{\circ}\right)$ & 33.138 & $<0.0001$ & 1.060 & 0.303 & 2.892 & 0.894 \\
\hline Salinity & 50.097 & $<0.0001$ & 0.233 & 0.628 & 1.968 & 0.961 \\
\hline $\mathrm{pH}$ & 37.700 & $<0.0001$ & 0.507 & 0.082 & 9.719 & 0.2051 \\
\hline SPM (mg/L) & 51.155 & $<0.0001$ & 0.006 & 0.934 & 0.720 & 0.998 \\
\hline DO (mg/L) & 46.525 & $<0.0001$ & 0.275 & 0.600 & 3.437 & 0.841 \\
\hline BOD (mg/L) & 46.708 & $<0.0001$ & 0.249 & 0.617 & 8.366 & 0.301 \\
\hline
\end{tabular}
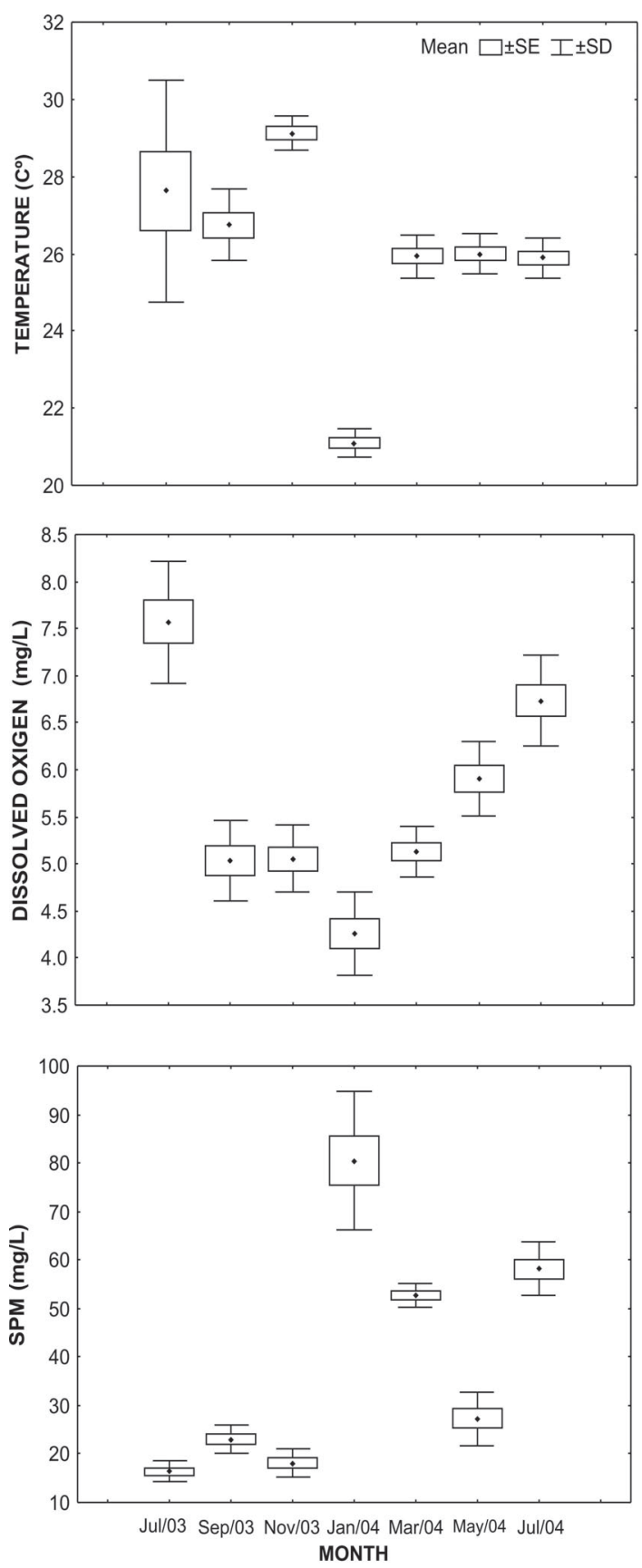

beginning with $C$. danae in July 2003 , followed by $C$. ornatus in the second semester of the year and, lastly, C. bocourti, which occurred in greater density in the first semester of 2004 (Figure 4). Callinectes bocourti was more abundant in the Curuçá creek (Figure 5A). C. danae density increased in the more external sites of the estuary in both creeks (Figure 5B).

Cluster analysis based on the abundance of each species revealed that the samples could be divided into three groups, with a cutoff point of $87 \%$ similarity (Figure 7). Group I included the months of January 2004 and
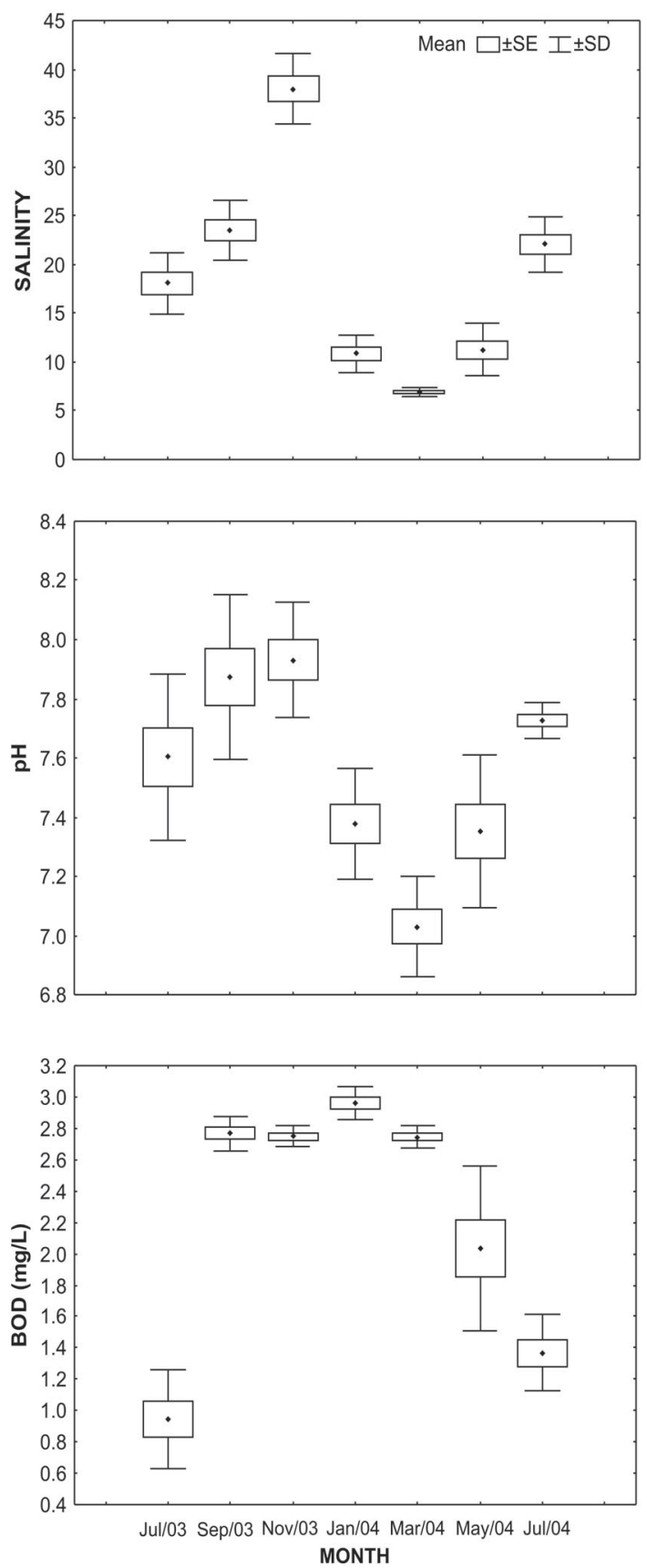

Figure 3 - Average bimonthly values, standard error (SE) and standard deviation (SD) of abiotic factors collected in the Curuçá estuary (PA) from July 2003 to July 2004. 
Table 3 - Results of the Kruskal-Wallis test for density regarding the different factors analyzed in the Curuçá estuary (PA) from July 2003 to July 2004 .

\begin{tabular}{lcccc}
\hline \hline Species & Month & Site & Creek & Season \\
\hline C. bocourti & $* *$ & ns & $*$ & $* *$ \\
C. danae & ns & $*$ & ns & ns \\
C. ornatus & ${ }^{*}$ & ns & ns & $*$ \\
\hline \hline
\end{tabular}
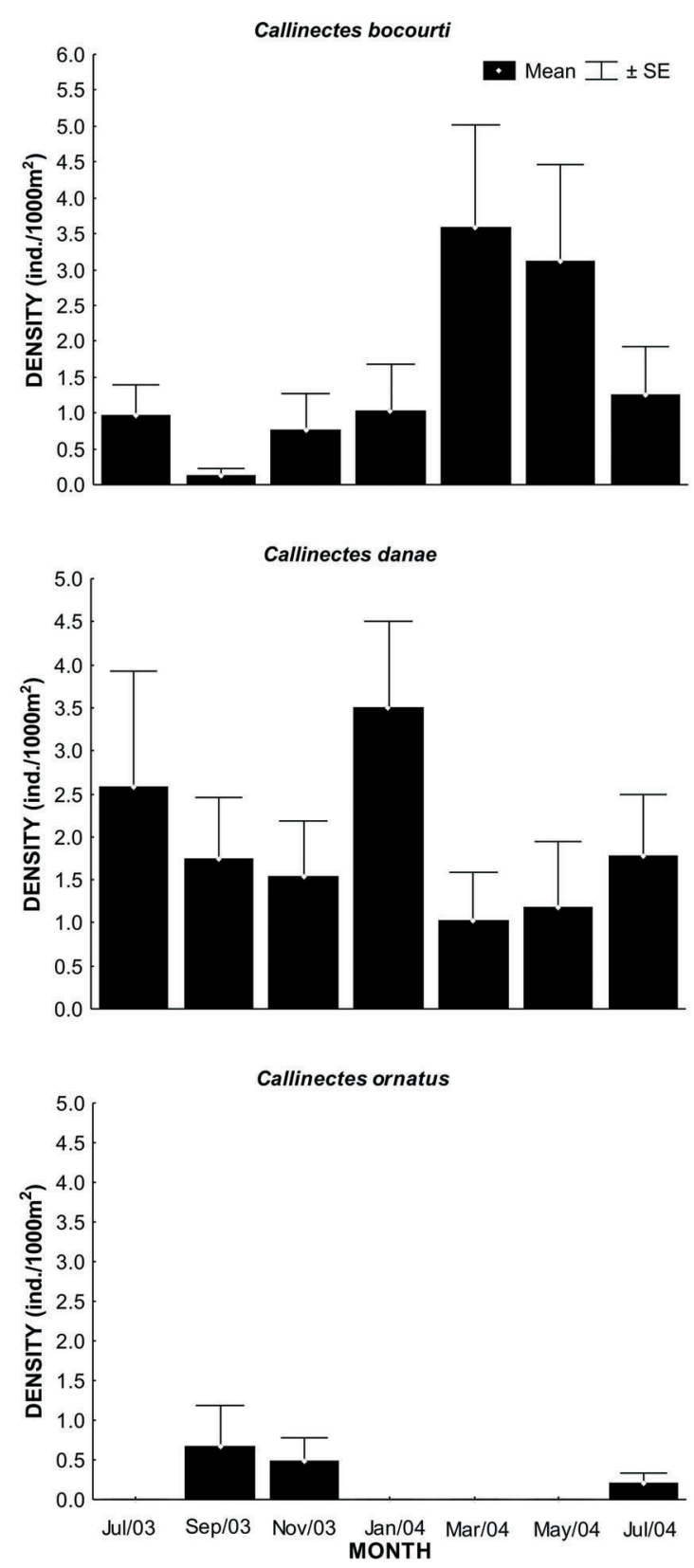

Figure 4 - Average monthly density of $C$. bocourti, $C$. danae and $C$. ornatus throughout the collection period in the Curuçá estuary (PA). Density is represented in different scales for the different species. SE=standard error.
July 2003, in which greater densities of $C$. danae were found. Group II was made up of March 2004 and May 2004, with a greater density of $C$. bocourti. Group III was formed by September 2003, November 2003 and July 2004, which were the only months in which there was the appearance of all three species (C. bocourti, $C$. danae and $C$. ornatus). The groups defined by cluster analysis (months) were also confirmed on the twodimensional plotting of the MDS and interpreted by the climatic season of the year: Group I occurred in both seasons (dry and rainy); Group II only occurred in the rainy season; and Group III only occurred in the dry season (Figure 8).

The SIMPER analysis revealed that Groups I and III had a greater contribution from C. danae and Group II had a greater contribution from C. bocourti (Table 4). Analyzing the individual or combined influence of the environmental variables on species distribution, correlation values no greater than 0.7 were found. Nonetheless, the variables that appear to best explain the pattern of species occurrence in the estuary are precipitation, salinity, $\mathrm{pH}$ and the interaction of these factors (Table 5).

\section{DISCUSSION}

The swimming crab community in the Curuçá estuary was represented by just three species. Studying swimming crabs in other estuaries in the northeast of the state of Pará, Cintra \& Silva (2002) also found the same three species, with $C$. bocourti as the most abundant species. This differs from the findings of the present study, in which $C$. danae was the most abundant species. Both studies found $C$. ornatus to be the least abundant species. Melo (1996) reports that $C$. ornatus occurs in areas with depths as great as $75 \mathrm{~m}$ and Cintra et al. (2003) collected the species on the coast of Pará at a depth of $65 \mathrm{~m}$. In the present study, collections were carried out in an estuarine area with shallow depths (under $5 \mathrm{~m}$ ), which may explain the low occurrence of this species throughout the study period.

Studies on distribution patterns for brachyurans in relation to the dynamics of abiotic factors stress the temperature and salinity of the water, which are considered extremely important for a better understanding of the dynamics of these crustaceans (Pinheiro, 1991). Variations in temperature and salinity have been cited by a number of authors as important factors for the occurrence of particular species from the genus Callinectes. The greatest catches of $C$. danae in eastern Porto Rico (Buchanan \& Stoner, 1988) and the city of Ubatuba (southeastern Brazil) (Chacur \& Negreiros-Fransozo, 2001) occur in waters with higher temperatures $\left(27\right.$ to $\left.28^{\circ} \mathrm{C}\right)$. Under laboratory conditions, 

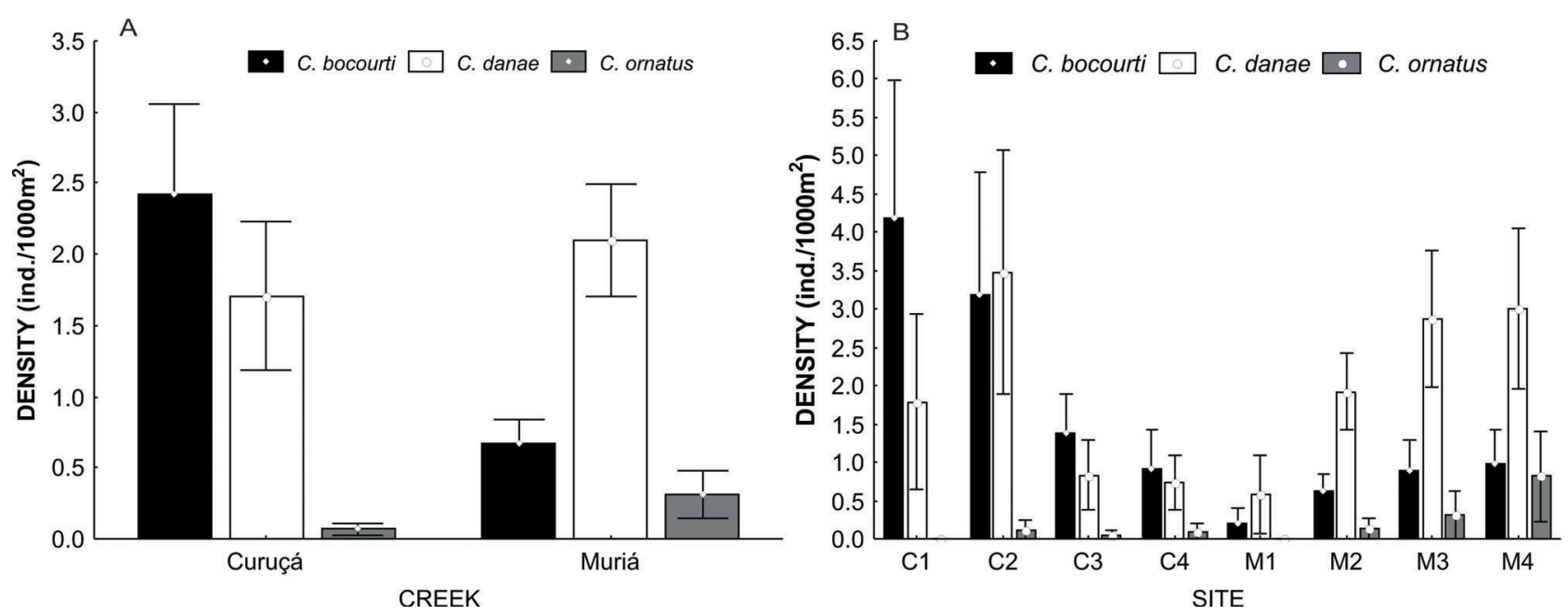

Figure 5 - Average density ( \pm standard error) of $C$. bocourti, $C$. danae and $C$. ornatus in relation to creeks and collection sites (A and B, respectively) from July 2003 to July 2004 in the Curuçá estuary (PA).

an increase in mortality rate was observed for Callinectes sapidus Rathbun, 1896 with a decrease in temperature and salinity (Rome et al., 2005). Salinity was found to be favorable to the abundance of Callinectes bellicosus Stimpson, 1859 in a coastal lake in Mexico (ArreolaLizárraga et al., 2003); Callinectes simillis Williams, 1966 exhibits a better growth rate in high salinity (Guerin \& Stickle, 1997). Róman-Contreras (1986) found that the entrance of $C$. sapidus, $C$. danae and $C$. ornatus in Términos Lake (México) tended to be greater when salinity increased.

In the present study, the factors that best explained the distribution of the swimming crabs in the estuary were precipitation, salinity and $\mathrm{pH}$. Oscillations in these environmental variables are related to the climatic season. An increase in salinity and $\mathrm{pH}$ is characteristic of the dry season, when the sea water penetrates the estuary in a greater volume as a result of reduced rainfall. Seasonal variations for the Curuçá estuary have also been described by Rosa Filho et al. (2007) that found a greater density of macrofauna from benthonic associations in the rainy period and a greater density of meiofauna in the dry season.

The difference in density between months, creeks and collection sites is explained by the ecological preferences of each species. Callinectes ornatus prefers more saline environments (Muriá Creek, Site M4) and, therefore, occurs in greater abundance in the dry season. Callinectes bocourti was more abundant in the rainy season, especially in the Curuçá Creek at the innermost site of the estuary $(C 1)$. These results are in agreement with findings described by Teixeira \& Sá (1998), who, in studying the abundance of decapod macrocrustaceans in shallow waters of the Mundaú Lake complex (state of Alagoas, northeastern Brazil), report that $C$. bocourti was more abundant in low salinity (values below 14), whereas $C$. ornatus was found in salinity values above
20. C. bocourti tolerates waters with low salinity, whereas $C$. ornatus more commonly occurs in waters with moderate salinity (18 to 35) (Mantelatto, 1995; Melo, 1996).

Callinectes danae appears to have a greater tolerance for variations in salinity, but prefers muddy substrates, such as those at sites C2, M2, M3 and M4. This fact has been cited by Melo (1996), who reports that the species has a great tolerance for salinity and may occupy estuaries, especially those with muddy sediments. Teixeira \& Sá (1998) found the same species related to the type of substrate in the Mundaú Lake complex (Alagoas). Thus, the inclusion of sediment type in future studies could be a valuable aspect in explaining the distribution of this species.

The three species have different ecological preferences. This is reinforced by the alternation in species over the months studied. The fact that the

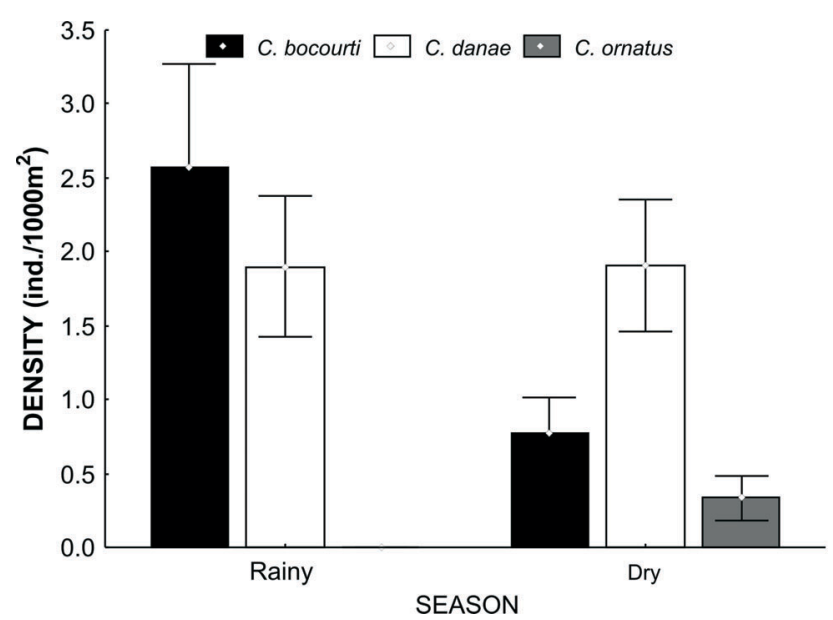

Figure 6 - Average density ( \pm standard error) of $C$. bocourti, $C$. danae and $C$. ornatus in relation to climatic season from July 2003 to July 2004 in the Curuçá estuary (PA). 
A

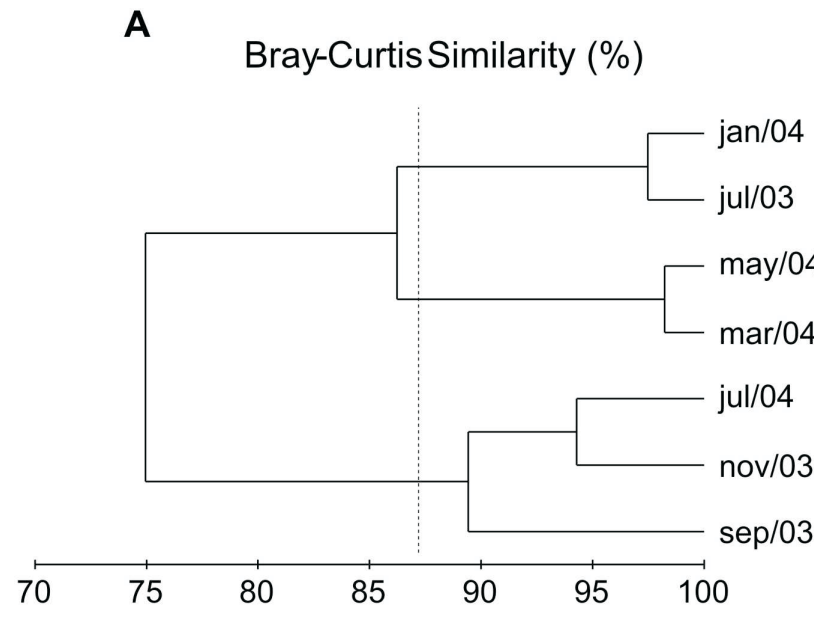

B

Density (\%)

Figure $7-A$ : Dendrogram of the cluster analysis on swimming crab species density in the Curuçá estuary (PA) from July 2003 to July 2004; B: Percentage of species density. Black $=$ C. bocourti; White $=C$. danae and Grey $=$ C. ornatus.

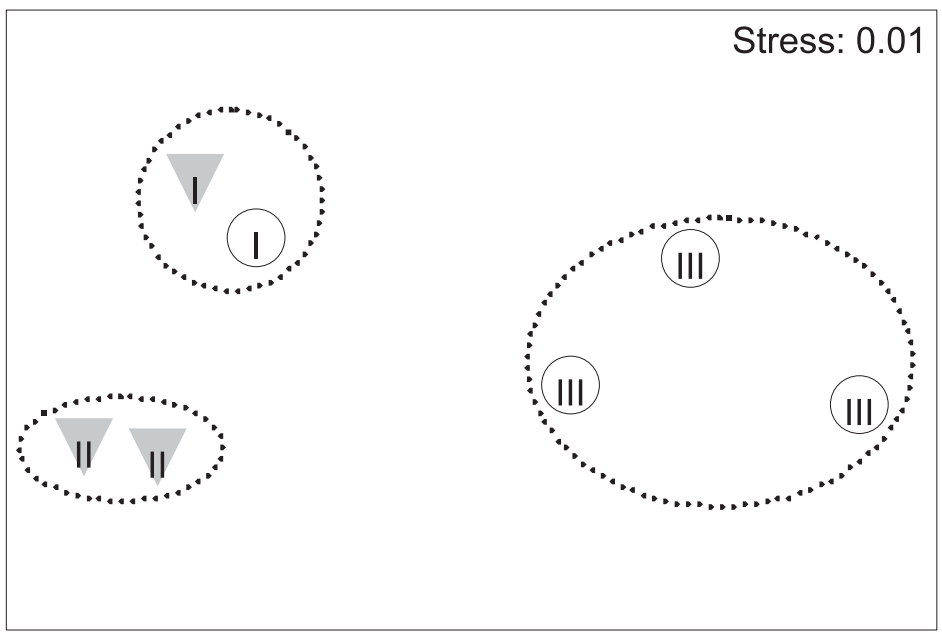

$\mathrm{D}$

$\mathrm{R}$

Figure 8 - Multidimensional scaling based on swimming crab species density in the Curuçá estuary (PA) from July 2003 to July 2004. $\mathrm{D}=$ Dry season; $\mathrm{R}$ = Rainy season.

Table 4 - Results of the SIMPER analysis indicating the percentage (\%) contribution of swimming crab species for the three groups formed in the cluster analysis. ASWG = average similarity within groups.

\begin{tabular}{|c|c|c|c|}
\hline Species & Group I & Group II & Group III \\
\hline ASWG (\%) & 87,84 & 93,00 & 93,00 \\
\hline C. bocourti & 27,16 & 75,25 & 14,50 \\
\hline C. danae & 72,84 & 24,75 & 71,96 \\
\hline C. ornatus & - & - & 13,54 \\
\hline
\end{tabular}

Table 5 - Correlation between environmental variables and species density obtained through BIOENV analysis.

\begin{tabular}{lc}
\hline \hline Variables & Correlation \\
\hline Precipitation, pH & 0.695 \\
Salinity, precipitation & 0.688 \\
Salinity, pH, precipitation & 0.688 \\
Precipitation & 0.681 \\
$\mathrm{pH}$ & 0.664 \\
Salinity & 0.571 \\
Salinity, pH & 0.569 \\
\hline \hline
\end{tabular}


species occupy the estuary in different seasons may be a strategy to avoid competition for food, as all three species are carnivorous and have basically the same food items in their diets (Branco, 1996; Mantelatto \& Chistofoletti, 2001; Branco et al., 2002).

The results of the present study demonstrate that variation in salinity and $\mathrm{pH}$ related to changes in precipitation may be considered determinants in the distribution of $C$. bocourti and $C$. ornatus. Moreover, the association of $C$. danae with sediment type should be studied further in order to explain its distribution in the Curuçá estuary.

\section{ACKNOWLEDGEMENTS}

The authors are grateful to the Coordenação de Aperfeiçoamento de Pessoal de Nível Superior (Brazilian Coordination of Upper Level Personnel Improvement) for the Master's grant given to the first author during the study; to the Instituto do Milênio (RECOS/CNPq) for the financial resources for the execution of the field collections; to the Pará State Secretary of Agriculture for support with the logistics of the fieldwork through the Curuperé Shrimp Farming Station; to the colleagues who helped in the field collections; and to Carla Tatiani Pereira for the hydrochemical analyses. All experiments conducted in this study complied with current applicable state and federal laws. My thanks are due to Richard Boike for the translation into the English language and to two anonymous reviewers for constructive comments on the manuscript.

\section{REFERENCES}

ANA-Agência Nacional das Águas. Dados Hidrológicos do Sistema de Informações Hidrológicas. 2004. Brasília-DF. Disponível em http://www.ana.gov.br.

Andrade, H.A.A. 1998. A produção da pesca industrial em Santa Catarina - Notas Técnicas da FACIMAR. Brazilian Journal of Aquatic Science and Technology. 2: 1-16.

Arreola-Lizárraga, J.A.; Hernández-Moreno, L.G.; Hernández-Vázquez, S.; Flores-Verdugo, F.J.; Lechuga-Devezé, C. \& Ortega-Rubio, A. 2003. Ecology of Callinectes arcuatus and $C$. bellicosus (Decapoda, Portunidae) in a coastal lagoon of northwest Mexico. Crustaceana. 76 (6): 651-664.

Baisch, P.; Lima, G.T.N. \& Griep, G. 2006. Caracterização Ambiental: Hidroquímica e Sedimentologia. Análise Granulométrica. In: Lana, P. C. L.; Bianchini, A.; Ribeiro, C.; Niencheski, L.F.H.; Fillmann, G. \& Santos, C.S.G. (eds.) Avaliação ambiental de estuários brasileiros: aspectos metodológicos. Editora do Museu Nacional, Rio de Janeiro. 14-62pp.
Baptista, C.; Pinheiro, M.A.A.; Blankensteyn, A \& Borzone, C.A. 2003. Estrutura populacional de Callinectes ornatus, Ordway (Crustacea, Portunidae) no Balneário Shangri-Lá, Pontal do Paraná, Paraná, Brasil. Revista Brasileira de Zoologia. 20 (4): 661666.

Barros, M.P.; Silva, S.B. \& Pimentel, F.R. 1997. Novos registros de Brachyura (Crustacea, Decapoda) para o litoral do estado do Pará, Brasil. Nauplius. 5 (2): 153-154.

Barros, M.P. \& Pimentel, F.R. 2001. A fauna de Decapoda (Crustacea) do Estado do Pará, Brasil: lista preliminar de espécies. Boletim do Museu Paraense Emilio Goeldi, Série Zoologia. 17 (1):1541.

Branco, J.O. 1996. Variações sazonais e ontogênicas na dieta natural de Callinectes danae Smith, 1869 (Decapoda: Portunidae) na Lagoa da Conceição, Florianópolis, SC. Arquivos de Biologia e Tecnologia. 39 (4): 999-1012.

Branco, J.O.; Lunardon-Branco, M.J.; Verani, J.R.; Schveitzer, R.; Souto, F.X. \& Vale, W.G. 2002. Natural diet of Callinectes ornatus Ordway, 1863 (Decapoda, Portunidae) in the Itapocoroy Inlet, Penha, SC, Brazil. Brazilian Archives of Biology and Technology. 45 (1): 35-40.

Branco, J.O. \& Fracasso, H.A.A. 2004. Biologia populacional de Callinectes ornatus, (Ordway) na Armação do Itapocoroy, Penha, Santa Catarina, Brasil. Revista Brasileira de Zoologia. 21 (1): 91-96.

Buchanan, B.A. \& Stoner, A.W. 1988. Distributional patterns of blue crabs (Callinectes sp) in a tropical Estuarine Lagoon. Estuaries. 11:231-239.

Cervigón, F.; Cipriani, R.; Fischer, W.; Garibaldi, L.; Hendrickx, M.; Lemus, A.J.; Márquez, R.; Poutiers, J.M.; Robaina, G. \& Rodriquez, B. 1992. Guia de Campo de las espécies comerciales marinas y de aguas salobres de la Costa Septentrional de Sur America. Fichas FAO de Identificación de espécies para los fines de la pesca. Preparado com el financiamento de la Comisión de Comunidades Europeas y de NORAD. FAO, Roma, 513p.

Chacur, M.M. \& Negreiros-Fransozo, M.L. 2001. Spatial and seasonal distributions of Callinectes danae (Decapoda, Portunidae) in Ubatuba Bay, São Paulo, Brazil. Journal of Crustacean Biology. 21 (2): 414425.

Cintra, I.H.A. \& Silva, K.C.A. 2002. Siris da família Portunidae Rafinisque, 1815, capturados em áreas estuarinas no nordeste paraense. Boletim TécnicoCientífico do CEPNOR. 2 (1): 109-127.

Cintra, I.H.A.; Silva, K.C.A.; Ramos-Porto, M. \& Viana, G.F.S. 2003. Siris capturados durante pescarias experimentais para o programa Revizee/Norte 
(Crustacea, Brachyura, Portunidae). Boletim Técnico-Científico do CEPNOR. 3 (1): 53-75.

Cunha, M.F.A. 2005. Comportamento alimentar de Centropomus pectinatus Poey, 1860 (Família Centropomidae) nas áreas entremarés do estuário do rio Curuçá-Pa. Trabalho de Conclusão de Curso. Universidade Federal do Pará - UFPA. 30p.

Guerin, J.L. \& Stickle, W.B. 1997. Effect of salinity on survival and bioenergetics of juvenile lesser blue crabs, Callinectes simillis. Marine Biology. 129: 6369.

Instituto do Milênio - Uso e Apropriação de Recursos Costeiros (RECOS). 2005. Rio Grande. Disponível em http://www.mileniodomar.org.br/.

Keunecke, K.A.; D'Incao, F.; Moreira, F.N.; Silva Jr., D.R. \& Verani, J.R. 2008. Idade e crescimento de Callinectes danae e C. ornatus (Crustácea, Decapoda) na Baía de Guanbara, Rio de Janeiro, Brasil. Iheringia, Série Zoologia. 98 (2): 231-235.

Mantelatto, F.L.M. 1995. Biologia reprodutiva de Callinectes ornatus Smith, 1869 (Crustacea, Decapoda, Portunidae) na região de Ubatuba (SP), Brasil. Tese de Doutorado. Instituto de Biociências - UNESP. 147p.

Mantelatto, F.L.M. \& Christofoletti, R. 2001. Natural feeding activity of the crab Callinectes ornatus (Portunidae) in Ubatuba Bay (São Paulo, Brazil): influence of season, sex, size and molt stage. Marine Biology. 138: 585-594.

Melo, G.A.S. 1996. Manual de identificação dos Brachyura (caranguejos e siris) do litoral brasileiro. Editora Plêiade, FAPESP, São Paulo, 603p.

Monteiro, D.P. 2005. Hábito alimentar de Juvenis de Lutjanus jocu (Bloch \& Shneider, 1801) (Lutjanidae) nos canais de maré do estuário do Rio Curuçá ( $\mathrm{Pa}$ - Brasil). Trabalho de Conclusão de Curso. Universidade Federal do Pará - UFPA. 32p.

Pauly, D. 1980. A selection of simple methods for the assessment of tropical fish stocks. FAO Fisheries Technical Paper, 729p.

Pereira, C.T.C.; Giarrizzo, T.; Jesus, A.J.S. \& Martinelli, J.M. 2007. Caracterização do efluente de cultivo de Litopenaeus vannamei no estuário do rio Curuçá (PA). In: Barroso, G.F.; Poersch, L.H.S. \& Cavalli, R.O. (eds.) Sistemas de cultivos aqüícolas na zona costeira do Brasil: recursos, tecnologias, aspectos ambientais e sócio econômicos. Editora do Museu Nacional, Rio de Janeiro. 291-301pp.
Pinheiro, M.A.A. 1991. Distribuição e Biologia Populacional de Arenaeus cribrarius (Lamarck, 1818) (Crustacea, Brachyura, Portunidae), na Enseada da Fortaleza, Ubatuba, SP. Dissertação de Mestrado. Instituto de Biociências - UNESP. 192p.

Róman-Contreras, R. 1986. Análisis de la población de Callinectes spp. (Decapoda: Portunidae) en sector occidental de la laguna de terminos, Campeche, Mexico. Anales del Instituto de Ciencias del Mar Y Limnología, Universidad Nacional Autónoma de México. 13 (1): 315-322.

Rome, M.S.; Young-Williams, A.C.; Davis, G.R. \& Hines, A.H. 2005. Linking temperature and salinity tolerance to winter mortality of Chesapeake Bay blue crabs (Callinectes sapidus). Journal of Experimental Marine Biology and Ecology. 319:129-145.

Rosa Filho, J.S.; Paula, J.H.C.; Barbosa, C.M.; Souza, A.L.B. 2007. Variações espaço-temporais na estrutura das associações bentônicas nas adjacências de uma fazenda de cultivo de camarão no estuário de Curuçá (PA). In: Barroso, G.F.; Poersch, L.H.S. \& Cavalli, R.O. (eds.) Sistemas de cultivos aqüícolas na zona costeira do Brasil: recursos, tecnologias, aspectos ambientais e sócio econômicos. Editora do Museu Nacional, Rio de Janeiro. 303-315pp.

Suguio, K. 1973. Introdução a sedimentalogia. Edgard Blücher, São Paulo, 317p.

Takeda, M. \& Okutani, T. 1983. Crustaceans and Mollusks trawled off Suriname and French Guiana. JAMARC - Japan Marine Fishery Resource Research Center, Tokio, 354p.

Teixeira, R.L. \& Sá, H.S. 1998. Abundância de macrocrustáceos decápodas nas áreas rasas do complexo lagunar Mundaú/Manguaba, AL. Revista Brasileira de Biologia. 58 (3): 393-494.

Vieira, J.P.; Vasconcellos, M.C.; Silava, R.E. \& Fischer, L.C. 1996. A ictiofauna acompanhante da pesca do camarão-rosa (Penaeus paulensis) no estuário da Lagoa dos Patos, RS, Brasil. Atlântica. 18: 123142.

Williams, A.B. 1974. The swimming crabs of the genus Callinectes (Decapoda, Portunidae). Fishery Bulletin. 72 (3): 685-798.
Submetido: Outubro/2008 Revisado: Dezembro/2008 Aceito: Fevereiro/2009 